\title{
Assessing the determinant Factors leading to Academic Staffs' level of Satisfaction and Turnover Intention in Universities, In Case of the Amhara Region, Ethiopia.
}

Kidanemariam Alem Berhie ( $\nabla$ kidanemariam2012@gmail.com )

Mekelle https://orcid.org/0000-0003-3772-2456

Kasim Mohammed

University of Gondar

Yibeltal Arega

University of Gondar College of Natural and Computational Sciences

Dessie Melese

University of Gondar College of Natural and Computational Sciences

Adem Ibrahim

University of Gondar College of Natural and Computational Sciences

Jemila Hussen

University of Gondar College of Natural and Computational Sciences

\section{Research}

Keywords: Academic Staff, Satisfaction, University, Turn Over Intention, Ordinal Logistic

Posted Date: March 11th, 2020

DOI: https://doi.org/10.21203/rs.3.rs-16699/v1

License: (c) (i) This work is licensed under a Creative Commons Attribution 4.0 International License.

Read Full License 


\section{Abstract}

Background: Job satisfaction is the most interesting field for many researchers to study work attitude in workers. Employee job satisfaction is fulfillment, gratification, and enjoyment that comes from work. The main objective of this study is to identify and analyze the determinant factors leading to academic staff's satisfaction and turnover intention in the Amhara regional state universities.

Methods: The study was conducted in seven Amhara regional state government universities. Crosssectional stratified sampling design was used. The stratum is based on these seven universities in Amhara regional state. In this investigation, ordinal logistic regression model was used.

Results: The study covers 620 respondents from September 2016 up to August, 2017. The sample staffs surveyed from UOG, BDU, Wollo, Debre-Birihan, Debre-Markos, Debre-Tabor and Welidiya University were $21.3 \%, 23.7 \%, 9.4 \%, 7.6 \%, 14.5 \%, 12.1 \%$ and $11.5 \%$, respectively. From these total respondents, $34.4 \%$ were satisfied with their job. From the total sample staff surveyed in the study, $26.0 \%$ were dissatisfied. $9.2 \%, 29.8 \%$ and $0.6 \%$ of the respondents were very dissatisfied, neutral and very satisfied in their jobs, respectively. $38.5 \%$ of the respondents were very eager to leave their job areas.

Conclusions: The independent variables sex, age, place of birth, employer University, job position, responsibility, advancement, salary, achievement, work condition, work itself and turnover have significant relation with an academic job satisfaction.

\section{Introduction}

Mostly employers pay close attention to the subjective well-being of their employees and its impact on their jobs. The European Union has called the attention of member states to the quality aspects of work and highlighted the importance of improving job quality to promote employment and social inclusion (European Commission, 2002).

Organizations around the world are striving to be the best in attracting and retaining its employees. Various strategies have been practiced and implemented to attract and retain employees in the organization in order to reduce the turnover rate (Agarwala T, 2007).

Education is widely recognized as one indicator of development. Employees who have a high level of job satisfaction commit their time, energy and efforts to work which results in high productivity (Scott, 2004).

Job satisfaction is the most interesting field for many researchers to study work attitude in workers. Positive and favorable attitudes towards the job indicates job satisfaction (Armstrong, 2006). Employee job satisfaction is the fulfillment, gratification, and enjoyment that comes from work. It is not the money or the fringe benefits, but the feelings employees receive from the work itself (Asegid et al., 2014).

Teachers are the most important resources within the university. They are the key figures for any changes needed in university. The provision of a high-quality education system depends on high-quality teachers 
(Jyoti and Sharma, 2006).

Job satisfaction, which has been studied widely by organizational researchers and has been linked to organizational commitment as well as to organizational performance (Mathieu, 1991, Ostroff, 1992).

Turnover intention is defined as the intention of workers to leave their job (Cho and Lewis, 2012).

\section{Statement Of The Problem}

Recent years have seen a proliferation of work on the topic of service quality. Many researchers have extensively investigated the nature of service quality and customer satisfaction (Harry, et al, 2007). Research in the area of the customer's perception of overall service quality in universities as indicated earlier is scanty. This is especially so with the Ethiopian universities. Many types of research related to this have been done outside Africa. For instance, Brookes, 2002 evaluated the student's experience in the UK, using a longitudinal survey. Richardson (2003) examined social presence in online courses in relation to students' perceived learning and satisfaction in New York. Universities are knowledge-based organizations and their success relies merely on the expertise, competencies, and excellence of their employees. Thus, the successful university has to be able to retain their valuable and talented human resources effectively addressing their expectations and needs and becoming the place for everybody feel and do their best.

The work of Zeithmal et al. (2009) suggests that one of the prime issues of poor performance in service organizations do not know customers $\rrbracket$ expectations. Thus, institutions of higher learning are bound to fail if they do not have an accurate understanding of what customers expect of them.

A number of studies have addressed the level of satisfaction and turnover intention among employees in the organization. However, such studies are limited in that none of them has been conducted academic staffs' employees in Amhara regional state universities. Thus, investigation of determinant factors leading to academic staffs' level of satisfaction and turnover intention has a paramount role.

\section{General Objectives}

The main objective of this study is to identify and analyze the determinant factors leading to academic staff satisfaction and turnover intention in the Amhara regional state universities.

\section{Specific Objective}

- To determine the effect of demographic variables on the academic staff satisfaction level.

- To assess the effect of work environment-related variables on the academic staff satisfaction level.

- To investigate the variation of academic staff satisfaction level across the universities.

\section{Material \& Methods}




\section{Description of the Study Area and Population}

The study was conducted in seven Amhara regional state government universities from September 2016 up to August 2017.

\section{Data}

The data were collected from the current academic staff of seven Amhara regional state universities. The instrument to be used for data collection was a self-administered questionnaire. Relevant documents and some statistical data were taken from the office of the registrar, human resource management office of the different universities as secondary data sources.

\section{Study Population}

The study population was randomly selected academic staff members in all seven universities.

\section{Sampling Design and Procedures}

The cross-sectional stratified sampling design was used. The stratum is based on these seven universities in Amhara regional state. The main purpose of stratification is to reduce sampling error, in order to increase efficiency. It involves the division or stratification of a population by partitioning the sampling frame into non-overlapping and relatively homogeneous groups.

\section{Sample Size Determination}

Determining the adequate sample size is the most important decision that faces the researcher. Usually, sample size is determined based on the sampling technique. Since prior information is lacking, a pilot survey was conducted to estimate the success probability $(p)$ and to pre-test the designed questionnaire. The values of the success probabilities of academic staff satisfaction level estimated based on the results of the pilot survey were $33 \%$. And the final sample size is 620 academic staff.

The response/dependent variables: overall satisfaction level of the academic staff related to services (academics, administration, work environment and other support resources of the university). The response categories are defined as in ordinal classifications and it has five components. The ordinal category ranges ( $1=$ Very dissatisfied; $2=$ Dissatisfied, $3=$ Neutral, $4=$ Satisfied and $5=$ Very satisfied). Turnover intention: 1 = Very unlikely, 2=Unlikely, 3=Neutral, 4=Likely, 5=Very likely based on the employee's intention to turn over from the university in the future.

\section{Ordinal Logistic Regression Model}

In this investigation, ordinal logistic regression model was used. The OLR procedure empowers one to select the predictive model for ordered dependent variables. OLR or (ordinal regression) is used to predict an ordinal dependent variable given one or more independent variables. 


\section{Results}

The statistical analysis first conducted using descriptive statistics. The study covers 620 respondents from Amhara Regional State Universities. The sample collected from seven Amhara regional state universities. The sample staffs surveyed from UOG, BDU, Wollo, Debre-Birihan, Debre-Markos, DebreTabor and Welidiya University were $21.3 \%, 23.7 \%, 9.4 \%, 7.6 \%, 14.5 \%, 12.1 \%$ and $11.5 \%$, respectively. $13.5 \%, 15.5,8.1 \%, 30 \%, 13.5 \%$ and 19.45 of the sample surveyed staffs their respective college was CART, CBEC, CMHS, CNCS, CSSH, and IOTE. From these total respondents, $34.4 \%$ (213) were satisfied with their job. From the total sample staff surveyed in the study, $26.0 \%$ were dissatisfied. $9.2 \%, 29.8 \%$ and $0.6 \%$ of the respondents were very dissatisfied, neutral and very satisfied in their jobs, respectively. $38.5 \%$ of the respondents were very eager to leave their job area. $22.1 \%$ of the respondents have the interest to leave their working areas. From 620 sample staffs in Amhara Regional universities $84.4 \%$ were male and the remaining $15.6 \%$ were female. $14.5 \%, 54.7 \%, 26.8 \%$ \& $4 \%$ of the respondents were under the age of $20-24$, $25-30,31-40,41 \&$ above respectively. $56.3 \%$ of the sample staffs their place of birth was rural and $43.7 \%$ of staff came from an urban area. $32.1 \%$ of the respondents have BSc/BA, $62.9 \%$ of the respondents have a master and the remaining $5 \%$ have a PhD. From 620 sample staffs $44.8 \%, 51.1 \%, 4 \%$ earn net income between 3500-8000, 8001-13000 and 13001 and above birr, respectively. From the total respondents, $76.6 \%$ their religion was Orthodox, $13.4 \%$ of the respondents were Muslim and the remaining $6.1 \%$ and $3.5 \%$ of the respondents were Protestant and Others, respectively. $45.2 \%, 53.9 \%$ and $1 \%$ of the sample Amhara university staff were married, single and other, respectively. From the total samples $54.2 \%, 41.6 \%$ and $4.2 \%$ of the respondent have a length of service $1-5 y$ ears, $6-10 y e a r s$ and 11 \& above, respectively. $2.1 \%, 8.5 \%, 12.6 \%$ and $76.8 \%$ of the respondents their job position was Director/dean/Vice Dean, Department Head, Coordinator, and no position, respectively.

Table 1: Reliability statistics for each variable, Amhara Region University, 2017. 


\begin{tabular}{ll}
\hline Variable & $\begin{array}{l}\text { Cronbach's } \\
\text { Alpha }\end{array}$ \\
& 0.828 \\
Achievement & 0.748 \\
Work status & 0.757 \\
Work condition & 0.665 \\
Growth & 0.737 \\
University policies & 0.811 \\
Advancement & 0.694 \\
Security & 0.637 \\
Teaching Process & 0.856 \\
Responsibility & 0.775 \\
Interpersonal Relations & \\
Surnovision & 0.600 \\
\hline
\end{tabular}

From the above table we see that the reliability of most of the variables was in a good level. So, we can use these variables to assess the factors that satisfied/dissatisfied the employee's work satisfaction and turnover intention using an appropriate statistical method.

Table 2: Distribution of independent variables with their level using Percentage and frequency on job satisfaction, Amhara Region University, 2017. 


\begin{tabular}{|c|c|c|c|c|c|c|}
\hline \multirow[t]{2}{*}{ Variable } & \multicolumn{6}{|c|}{ Job Satisfaction } \\
\hline & Level & V. dissatisfied & Dissatisfied & Neutral & Satisfied & V. satisfied \\
\hline \multirow[t]{5}{*}{ Restaurant } & Str.disagree & $17(29.8 \%)$ & $52(32.3 \%)$ & $45(24.3 \%)$ & $50(23.5 \%)$ & $2(50 \%)$ \\
\hline & Disagree & $26(45.6 \%)$ & $53(32.9 \%)$ & $65(35.1 \%)$ & $64(30.0 \%)$ & $1(25 \%)$ \\
\hline & Neutral & $12(21.1 \%)$ & $39(24.2 \%)$ & $54(29.2 \%)$ & $53(24.9 \%)$ & $0(0 \%)$ \\
\hline & Agree & $1(1.8 \%)$ & $15(9.3 \%)$ & $15(8.1 \%)$ & $39(18.3 \%)$ & $1(25 \%)$ \\
\hline & Str. Agree & $1(1.8 \%)$ & $2(1.2 \%)$ & $6(3.2 \%)$ & $7(3.3 \%)$ & $0(0 \%)$ \\
\hline Instructional & Str.disagree & 7(12.3\%) & $16(9.9 \%)$ & $15(8.1 \%)$ & $8(3.8 \%)$ & $2(50 \%)$ \\
\hline \multirow[t]{4}{*}{ Support } & Disagree & $23(40.4 \%)$ & $53(32.9 \%)$ & $57(30.8 \%)$ & $37(17.4 \%)$ & $0(0 \%)$ \\
\hline & Neutral & $19(33.3 \%)$ & $66(41 \%)$ & $67(36.2 \%)$ & $91(42.7 \%)$ & $1(25 \%)$ \\
\hline & Agree & $8(14 \%)$ & $21(13 \%)$ & $38(20.5 \%)$ & $67(31.5 \%)$ & $0(0 \%)$ \\
\hline & Str. Agree & $0(0 \%)$ & $5(3.1 \%)$ & $8(4.3 \%)$ & $10(4.7 \%)$ & $0(0 \%)$ \\
\hline \multirow[t]{6}{*}{ Supervision } & Str.disagree & $5(8.8 \%)$ & $13(8.1 \%)$ & $7(3.8 \%)$ & $2(0.9 \%)$ & $0(0 \%)$ \\
\hline & Disagree & $26(45.6 \%)$ & $58(36 \%)$ & $45(24.3 \%)$ & $26(12.2 \%)$ & $2(50 \%)$ \\
\hline & Neutral & 18(31.6\%) & $75(46.6 \%)$ & $91(49.2 \%)$ & $100(46.9 \%)$ & $2(50 \%)$ \\
\hline & Agree & $8(14 \%)$ & $15(9.3 \%)$ & $39(21.1 \%)$ & $82(38.5 \%)$ & $0(0 \%)$ \\
\hline & Str.agree & $0(0 \%)$ & $0(0 \%)$ & $3(1.6 \%)$ & $3(1.4 \%)$ & $0(0 \%)$ \\
\hline & Str.disagree & $3(5.3 \%)$ & $3(1.9 \%)$ & $2(1.1 \%)$ & $0(0 \%)$ & $0(0 \%)$ \\
\hline Interpersonal & Disagree & $9(15.8 \%)$ & $25(15.5 \%)$ & $18(9.7 \%)$ & $8(3.8 \%)$ & $0(0 \%)$ \\
\hline \multirow[t]{4}{*}{ Relations } & Neutral & 17(29.8\%) & $55(34.2 \%)$ & $48(25.9 \%)$ & $27(12.7 \%)$ & $4(100 \%)$ \\
\hline & Agree & $25(43.9 \%)$ & $70(43.5 \%)$ & $93(50.3 \%)$ & $140(65.7 \%)$ & $0(0 \%)$ \\
\hline & Str.agree & $3(5.3)$ & $8(5 \%)$ & $24(13 \%)$ & $38(17.8 \%)$ & $3(50 \%)$ \\
\hline & Str.disagree & $21(36.8 \%)$ & $28(17.4 \%)$ & $10(5.4 \%)$ & $6(2.8 \%)$ & 0 \\
\hline \multirow[t]{4}{*}{ Responsibility } & Disagree & $23(40.4 \%)$ & $79(49.1 \%)$ & $61(33 \%)$ & $36(16.9 \%)$ & 0 \\
\hline & Neutral & $8(14 \%)$ & $43(26.7 \%)$ & $71(38.4 \%)$ & $78(36.6 \%)$ & $4(100 \%)$ \\
\hline & Agree & $4(7 \%)$ & $11(6.8 \%)$ & $40(21.6 \%)$ & $80(37.6 \%)$ & 0 \\
\hline & Str.agree & $1(1.8 \%)$ & $0(0 \%)$ & $3(1.6 \%)$ & $13(6.1 \%)$ & 0 \\
\hline \multirow[t]{5}{*}{ Teaching Process } & Str.disagree & $5(8.8 \%)$ & $10(6.2 \%)$ & $9(4.9 \%)$ & $1(0.5 \%)$ & 0 \\
\hline & Disagree & $25(43.9 \%)$ & $66(41 \%)$ & $55(29.7 \%)$ & $28(13.1 \%)$ & $2(50 \%)$ \\
\hline & Neutral & 17(29.8\%) & $69(42.9 \%)$ & $78(42.2 \%)$ & 103(48.4\%) & $2(50 \%)$ \\
\hline & Agree & $10(17.5 \%)$ & 14(8.7\%\%) & $42(22.7 \%)$ & $72(33.8 \%)$ & 0 \\
\hline & Str.agree & 0 & $2(1.2 \%)$ & $1(0.5 \%)$ & $9(4.2 \%)$ & 0 \\
\hline \multirow[t]{5}{*}{ Security } & Str.disagree & $5(8.8 \%)$ & $9(5.6 \%)$ & $5(2.7 \%)$ & $3(1.4 \%)$ & 0 \\
\hline & Disagree & $14(24.6 \%)$ & $23(14.3 \%)$ & $25(13.5 \%)$ & $20(9.4 \%)$ & 0 \\
\hline & Neutral & 13(22.8\%) & $56(34.8 \%)$ & $49(26.5 \%)$ & $36(16.9 \%)$ & $2(50 \%)$ \\
\hline & Agree & $22(38.6 \%)$ & $58(36 \%)$ & $76(41.1 \%)$ & $98(46 \%)$ & $1(25 \%)$ \\
\hline & Str.agree & $3(5.3 \%)$ & $15(9.3 \%)$ & $30(16.2 \%)$ & $56(26.3 \%)$ & $1(25 \%)$ \\
\hline \multirow[t]{5}{*}{ Advancement } & Str.disagree & 13(22.8\%) & $9(5.6 \%)$ & $5(2.7 \%)$ & 0 & 0 \\
\hline & Disagree & 19(33.3\%) & $57(35.4 \%)$ & $32(17.3 \%)$ & 18(8.5\%) & 0 \\
\hline & Neutral & 13(22.8\%) & 64(39.8\%) & $85(45.9 \%)$ & $56(26.3 \%)$ & $2(50 \%)$ \\
\hline & Agree & 11(19.3\%) & $29(18.0 \%)$ & $52(28.1 \%)$ & $111(52.1 \%)$ & $1(25 \%)$ \\
\hline & Str.agree & $1(1.8 \%)$ & $2(1.2 \%)$ & $11(5.9 \%)$ & $28(13.1 \%)$ & $1(25 \%)$ \\
\hline \multirow[t]{5}{*}{ Salary } & Str.disagree & $4(7 \%)$ & $7(4.3 \%)$ & $9(4.9 \%)$ & $4(1.9 \%)$ & 0 \\
\hline & Disagree & $14(24.6 \%)$ & $37(23 \%)$ & $22(11.9 \%)$ & $43(20.2 \%)$ & 0 \\
\hline & Neutral & $21(36.8 \%)$ & $61(37.9 \%)$ & $82(44.3 \%)$ & $73(34.3 \%)$ & 0 \\
\hline & Agree & $9(15.8 \%)$ & $39(24.2 \%)$ & $52(28.1 \%)$ & $65(30.5 \%)$ & $3(75 \%)$ \\
\hline & Str. Agree & $9(15.8 \%)$ & $17(10.6 \%)$ & $20(10.8 \%)$ & $28(13.1 \%)$ & $1(25 \%)$ \\
\hline \multirow[t]{5}{*}{ University policies } & Str.disagree & $7(12.3 \%)$ & $7(4.3 \%)$ & $6(3.2 \%)$ & $3(1.4 \%)$ & 0 \\
\hline & Disagree & $23(40.4 \%)$ & $54(33.5 \%)$ & $28(15.1 \%)$ & $19(8.9 \%)$ & 0 \\
\hline & Neutral & $20(35.2 \%)$ & $74(46 \%)$ & $83(44.9 \%)$ & $76(35.7 \%)$ & $2(50 \%)$ \\
\hline & Agree & $5(8.8 \%)$ & $25(15.5 \%)$ & $62(33.5 \%)$ & $100(46.9 \%)$ & $2(50 \%)$ \\
\hline & Str.agree & $2(3.5 \%)$ & $1(0.6 \%)$ & $6(3.2 \%)$ & $15(7 \%)$ & 0 \\
\hline Work status & Str.disagree & $3(5.3 \%)$ & $5(3.1 \%)$ & $5(2.7 \%)$ & $2(0.9 \%)$ & 0 \\
\hline
\end{tabular}




\begin{tabular}{|c|c|c|c|c|c|c|}
\hline & Disagree & 17(29.8\%) & $31(19.3 \%)$ & $17(9.2 \%)$ & $7(3.3 \%)$ & 0 \\
\hline & Neutral & 19(33.3\%) & $58(36 \%)$ & $67(36.2 \%)$ & $37(17.4 \%)$ & 0 \\
\hline & Agree & 11(19.3\%) & $57(35.4 \%)$ & $74(40 \%)$ & $128(60.1 \%)$ & $3(75 \%)$ \\
\hline & Str. Agree & 7(12.3\%) & $10(6.2 \%)$ & $22(11.9 \%)$ & $39(18.3 \%)$ & $1(25 \%)$ \\
\hline Work & Str.disagree & $4(7 \%)$ & $6(3.7 \%)$ & $2(1.1 \%)$ & 0 & $1(25 \%)$ \\
\hline \multirow[t]{4}{*}{ Condition } & Disagree & $25(43.9 \%)$ & $48(29.8 \%)$ & $24(13 \%)$ & $7(3.3 \%)$ & 0 \\
\hline & Neutral & 19(33.3\%) & $80(49.7 \%)$ & $99(53.5 \%)$ & $76(35.7 \%)$ & 0 \\
\hline & Agree & $9(15.8 \%)$ & $27(16.8 \%)$ & $54(29.2 \%)$ & $111(52.1 \%)$ & $2(50 \%)$ \\
\hline & Str.agree & 0 & 0 & $6(3.2 \%)$ & 19(8.9\%) & $1(25 \%)$ \\
\hline \multirow[t]{5}{*}{ Achievement } & Str.disagree & $4(7 \%)$ & $6(3.7 \%)$ & $8(4.3 \%)$ & $3(1.4 \%)$ & 0 \\
\hline & Disagree & $16(28.1 \%)$ & $41(25.5 \%)$ & $19(10.3 \%)$ & $7(3.3 \%)$ & 0 \\
\hline & Neutral & $16(28.1 \%)$ & $38(23.6 \%)$ & $42(22.7 \%)$ & $17(8 \%)$ & 0 \\
\hline & Agree & $13(22.8 \%)$ & $62(38.5 \%)$ & $89(48.1 \%)$ & $132(62 \%)$ & $2(50 \%)$ \\
\hline & Str.agree & $8(14 \%)$ & 14(8.7\%) & $27(14.6 \%)$ & $54(25.4 \%)$ & $1(25 \%)$ \\
\hline \multirow[t]{5}{*}{ Growth } & Str.disagree & $15(26.3 \%)$ & $18(11.2 \%)$ & $9(4.9 \%)$ & $5(2.3 \%)$ & 0 \\
\hline & Disagree & $16(28.1 \%)$ & $57(35.4 \%)$ & $45(24.3 \%)$ & $29(13.6 \%)$ & 0 \\
\hline & Neutral & $11(19.3 \%)$ & $60(37.3 \%)$ & $74(40 \%)$ & $58(27.2 \%)$ & $2(50 \%)$ \\
\hline & Agree & $10(17.5 \%)$ & $21(13 \%)$ & $50(27 \%)$ & $92(43.2 \%)$ & $1(25 \%)$ \\
\hline & Str.agree & $5(8.8 \%)$ & $5(3.1 \%)$ & $7(3.8 \%)$ & $29(13.6 \%)$ & 0 \\
\hline \multirow[t]{5}{*}{ Work itself } & Str.disagree & $11(19.3 \%)$ & $9(5.6 \%)$ & $5(2.7 \%)$ & $10(4.7 \%)$ & 0 \\
\hline & Disagree & $16(28.1 \%)$ & $58(36 \%)$ & $60(32.4 \%)$ & $50(23.5 \%)$ & $2(50 \%)$ \\
\hline & Neutral & 16(28.1\%) & $74(46 \%)$ & $92(49.7 \%)$ & $92(43.2 \%)$ & 0 \\
\hline & Agree & 11(19.3\%) & $16(9.9 \%)$ & $24(13 \%)$ & $56(26.3 \%)$ & $2(50 \%)$ \\
\hline & Str. Agree & $3(5.3 \%)$ & $4(2.5 \%)$ & $4(2.2 \%)$ & $5(2.3 \%)$ & 0 \\
\hline \multirow[t]{5}{*}{ Turnover } & Str.disagree & $6(10.5 \%)$ & $2(1.2 \%)$ & $6(3.2 \%)$ & $16(7.5 \%)$ & $3(75 \%)$ \\
\hline & Disagree & $5(8.8 \%)$ & $31(19.3 \%)$ & $20(10.8 \%)$ & $48(22.5 \%)$ & 0 \\
\hline & Neutral & $15(26.3 \%)$ & $51(31.7 \%)$ & $100(54.1 \%)$ & $78(36.6 \%)$ & 0 \\
\hline & Agree & $10(17.5 \%)$ & $57(35.4 \%)$ & $50(27 \%)$ & $61(28.6 \%)$ & 0 \\
\hline & Str. Agree & $21(36.8 \%)$ & $20(12.4 \%)$ & $9(4.9 \%)$ & $10(4.7 \%)$ & $1(25 \%)$ \\
\hline
\end{tabular}

From the above table we see that the distribution of strongly agree and very satisfied was very low. But the distribution level of neutral and below neutral with the corresponding level of neutral and below neutral on job satisfaction was higher. Especially, most of the respondents decide on a neutral level. Next to this, we used a statistical test and model in order to strengthen our evidence and to investigate factors that affect job satisfaction of Amhara state university academic staff.

\section{Chi-square Test of Association}

To see the association between one of the risk factors (independent variables) and the dependent variable (job satisfaction), by taking each of the independent variables at a time with the dependent variable job satisfaction, the Pearson Chi-square $\left(\mathrm{X}^{2}\right)$ association was used.

Table 3: List of independent variables that have a significant association with job satisfaction, Amhara Region University, 2017. 


\begin{tabular}{|c|c|c|}
\hline \multirow[b]{2}{*}{ Variable } & \multicolumn{2}{|c|}{ Pearson Chi-square } \\
\hline & Value & p-value \\
\hline Sex & 1.746 & 0.782 \\
\hline Age & 10.343 & 0.323 \\
\hline Place of Birth & 9.363 & 0.025 \\
\hline Region & 24.942 & 0.409 \\
\hline Net Income & 2.615 & 0.855 \\
\hline Aca demic Level & 6.301 & 0.390 \\
\hline Religion & 6.449 & 0.694 \\
\hline Marital Status & 2.683 & 0.847 \\
\hline Employer University & 58.497 & 0.000 \\
\hline College & 39.953 & 0.000 \\
\hline Service Year & 1.757 & 0.941 \\
\hline Job Position & 13.079 & 0.159 \\
\hline Transport & 23.584 & 0.005 \\
\hline Supermarket \& Bank Service & 15.349 & 0.082 \\
\hline Internet \& computer & 20.747 & 0.014 \\
\hline Books, Journals \& Magazines & 17.667 & 0.039 \\
\hline Reward & 68.884 & 0.000 \\
\hline Restaurant & 22.273 & 0.008 \\
\hline Instructional Support & 49.166 & 0.000 \\
\hline Supervision & 84.802 & 0.000 \\
\hline Interpersonal Relations & 63.749 & 0.000 \\
\hline Responsibility & 151.400 & 0.000 \\
\hline Teaching Process & 77.019 & 0.000 \\
\hline Security & 38.047 & 0.000 \\
\hline Advancement & 135.500 & 0.000 \\
\hline Salary & 22.356 & 0.008 \\
\hline University Policies & 98.443 & 0.000 \\
\hline Work Status & 87.022 & 0.000 \\
\hline Achievement & 100.100 & 0.000 \\
\hline Work Condition & 153.200 & 0.000 \\
\hline Growth & 98.945 & 0.000 \\
\hline Work Itself & 30.713 & 0.000 \\
\hline Turnover & 77.198 & 0.000 \\
\hline
\end{tabular}

*significant (p-value < 0.05)

Table 3 revealed that; the variables employer university, college, transport, supermarket \& bank service, restaurant, reward, instructional support, supervision, interpersonal relationships, responsibility, teaching process, security, advancement, salary, university policies, work status, achievement, work condition, growth, work itself and turnover had a significant relationship $(p-v a l u e<0.05)$ with job satisfaction status of the respondent. Work-related variables were highly associated with overall job satisfaction. Most of the demographic variables were not statistically associated with job satisfaction. The variable that has a pvalue of less than 0.25 in univariate analysis, was a candidate for the ordinal logistic regression model. Sex and age incorporated in the model due to the management point of view and they are significant when we inter in the model.

Ordinal Logistic Regression model to determine factors that affect job Satisfaction 
The ordinal logistic regression model used to determine factors that affect the job satisfaction of employees. When we observe the fitted model there is a high reduction in the chi-square statistics $(p<0.001)$ so, the model is properly (significant) improve over the baseline or intercept only model from 1649.2 to 1221.44 on the log-likelihood, a chi-square difference of 431.751 and a $p$-value of less than 0.001 . The goodness of fit the model was summarized by Pearson and Deviance with their significant value. The chi-squared value with their $p$-value for Pearson and Deviance was 3322.339 ( $P$-value $<0.001$ ) and 1271.448 (P-value=1.00). Pseudo R-Square for Cox and Snell and Nagelkerke were 0.502 and 0.53, respectively. Much of the variation of the dependent variable explained by the model, is sufficient for the ordinal logistic model. Table 4 showed the estimates, the standard error of estimates, the Wald test value, the P-value, odds ratio and the $95 \%$ confidence intervals for estimating using proportional odds ordinal logistic regression model. The variables that have significant relation with academic job satisfaction were sex, age, place of birth, Employer University, job position, responsibility, advancement, salary, achievement, work condition, work itself and turnover.

Table 4: Results of Ordinal Logistic Regression Model using Proportional odds on Staff Job Satisfaction, Amhara Region University, 2017. 


\begin{tabular}{|c|c|c|c|c|c|c|}
\hline Predictor & B & $\mathrm{SE}$ & Wald & P-value. & HR & $95 \%$ CI for B \\
\hline Variables & & & & & & Lower Upper \\
\hline Sex (Ref. Female) & 0.575 & 0.265 & 4.697 & 0.030 & 1.777 & $0.055-0.575$ \\
\hline Age (20-24) (Ref. 3) & 1.438 & 0.526 & 7.480 & 0.006 & 4.212 & $0.408-2.469$ \\
\hline Age (25-30) & 1.237 & 0.462 & 7.171 & 0.007 & 3.445 & $0.332-2.142$ \\
\hline Age $(31-40)$ & 1.044 & 0.467 & 5.007 & 0.025 & 2.840 & $0.130-1.958$ \\
\hline Place birth (Ref. Urban) & 0.411 & 0.185 & 4.937 & 0.026 & 1.508 & $0.048-0.773$ \\
\hline Position (Top) (Ref. No Position) & -1.615 & 0.600 & 7.243 & 0.007 & 0.199 & $-2.792--0.439$ \\
\hline Responsibility (1) (Ref. 5) & -3.012 & 0.811 & 13.79 & 0.000 & 0.049 & $-4.602--1.423$ \\
\hline Responsibility (2) & -1.746 & 0.760 & 5.269 & 0.022 & 0.174 & $-3.236--0.255$ \\
\hline Advancement (1) (Ref. 5) & -1.886 & 0.669 & 7.954 & 0.005 & 0.152 & $-3.196--0.575$ \\
\hline Salary (2) (Ref. 1) & 1.304 & 0.505 & 5.640 & 0.010 & 3.684 & $0.313-2.294$ \\
\hline Achievement (2) (Ref. 5) & -1.144 & 0.419 & 7.448 & 0.006 & 0.318 & $-1.966--0.322$ \\
\hline Achievement (3) & -1.023 & 0.346 & 8.720 & 0.003 & 0.359 & $-1.702--0.344$ \\
\hline Work condition (2) (Ref. 5) & -2.622 & 0.686 & 14.59 & 0.000 & 0.072 & $-3.967--1.277$ \\
\hline Work condition (3) & -1.849 & 0.628 & 8.673 & 0.003 & 0.157 & $-3.080--0.618$ \\
\hline Work condition (4) & -1.376 & 0.608 & 5.127 & 0.024 & 0.252 & $-2.567--0.185$ \\
\hline Work itself (2) (Ref. 5) & 1.809 & 0.607 & 8.893 & 0.003 & 6.104 & $0.620-2.997$ \\
\hline Work itself (3) & 1.637 & 0.600 & 7.442 & 0.006 & 5.139 & $0.461-2.813$ \\
\hline Work itself (4) & 1.993 & 0.613 & 10.56 & 0.001 & 7.337 & $0.791-3.195$ \\
\hline Turnover (1) (Ref. 5) & 1.327 & 0.521 & 6.497 & 0.011 & 3.769 & $0.307-2.348$ \\
\hline Turnover (2) & 1.542 & 0.372 & 17.20 & 0.000 & 4.674 & $0.813-2.270$ \\
\hline Turnover (3) & 1.314 & 0.332 & 15.67 & 0.000 & 3.721 & $0.663-1.964$ \\
\hline Turnover (4) & 1.602 & 0.337 & 22.55 & 0.000 & 4.962 & $0.941-2.263$ \\
\hline University (0) (Ref. 6) & 1.350 & 0.344 & 15.36 & 0.000 & 3.857 & $0.675-2.025$ \\
\hline University (1) & 1.400 & 0.346 & 16.36 & 0.000 & 4.055 & $0.722-2.079$ \\
\hline University (2) & 1.601 & 0.425 & 14.18 & 0.000 & 4.958 & $0.768-2.434$ \\
\hline University (3) & 0.889 & 0.431 & 4.259 & 0.039 & 2.433 & $0.045-1.733$ \\
\hline
\end{tabular}


The estimated odds of being in the satisfaction level below any fixed level for males were 1.777 times the estimated odds for female staffs (males are more likely to be in higher satisfaction level as compared to females). The estimated odds of satisfaction level for staff whose ages between 20-24years, 25-30years, 31-40years were 4.212, 3.445 and 2.840 times higher than the estimated odd of staff whose ages 41 \& above, respectively. When the age of the worker's increases, they are more likely to have a lower satisfaction level. If university academic staff (teachers) palace of birth was rural, $50.8 \%$ higher for the satisfaction of any fixed level as compared to the reference group staff that came from an urban area.

Staff whose positions were top $80.1 \%$ less likely to satisfy below any fixed level as compared to no position staff. Staff who have no position more likely to be in higher satisfaction as compared to staff whose position was top management. Sample staffs (teachers) that found in Amhara state university whose opinion about responsibility was strongly disagreed. $95.1 \%$ less likely to satisfied below any fixed level verses higher as compared to staff whose opinion about responsibility strongly agrees. The odds of lower versus higher satisfaction were $82.6 \%$ less for teachers whose opinion disagree as compared to the reference group strongly agree for the variable responsibility. Staffs (teachers) that found in Amhara state university whose response about advancement was strongly disagree $84.8 \%$ less likely to satisfied below any fixed level as compared to staffs whose response about advancement strongly agree. The odds of lower versus higher satisfaction were 3.684 times higher for university teachers whose suggestions about salary disagree as compared to the reference category strongly disagree.

Sample staffs (teachers) that found in Amhara state university whose decision about achievement was disagreed and neutral $68.2 \%$ and $64.1 \%$ less likely to satisfied below any fixed level satisfaction as compared to staff whose decision about achievement strongly agrees, respectively. If you go to strongly disagree to strongly agree on the achievement component, the satisfaction level proportionally increased the satisfaction level from strongly dissatisfied to strongly satisfied. The odds of lower versus higher satisfaction was $92.8 \%, 84.3 \%$ and $74.8 \%$ less likely for teachers whose opinion disagree, neutral and agree as compared to the reference group strongly agree for the variable work condition, respectively.

The estimated odds of being in the satisfaction level below any fixed level verses higher for disagree, neutral and agree were 6.104, 5.139 and 7.337 times higher than the estimated odds for strongly agree for the variable work itself, respectively. The logarithms of the odds of satisfaction bellow any fixed level for very unlikely, unlikely, neutral and likely for turnover intention were 1.327, 1.542, 1.314 and 1.602 times the logarithm of the odds for very likely, respectively. The logarithms of the odds of satisfaction bellow any fixed level for staffs that work university of Gondar; Bahirdar University, Wollo University, and Debrebrhan University were 1.350, 1.400, 1.601 and 0.889 times the logarithm of the odds for Woldiay University, respectively.

\section{Discussion}

The study conducted to identify factors that affect the academic staff's job satisfaction using 620 sample staffs from Amhara state universities. $34.4 \%$ of the academic staff were satisfied with their job in 
the study area. This study supported by Uddin et al., 2016, 34.1\% of employees were satisfied by their job. The distributions of job satisfaction between female and male staff are different in this study. Male staff more likely to satisfied than of female staff. Another study shows that there is a significant difference in job satisfaction between male and female academic staff members, (Donald et al., 2016). The result also shows that age negatively related to overall job satisfaction. When the employee's age increased the overall satisfaction of the workers decreased. Studies conducted by Ramadhani (2014) using multiple regression found that age and job satisfaction were inversely related.

Job satisfaction of the academic staff highly related to the staff's turnover intention as we see using chisquare association and ordinal logistic regression (see Table $3 \& 4$ ). Academic staff were not satisfied by their job they are very eager to leave the organization soon. And also, if they are interested to leave the workplace they are not satisfied with their job. Other studies revealed that like Ali (2014), overall job satisfaction was found to have a significant negative association with turnover intention. Getie et al. (2013) carried out a cross-sectional study in East Gojjam Governmental health institution using a binary logistic regression model. The result indicated that job satisfaction and turnover intention directly or indirectly affect one to the other $(P=0.029,95 \%, \mathrm{Cl}=1.06-2.97)$.

The satisfaction levels of academic staff across the university were different in Amhara state university (see Table 4). This difference may be due to their experience and their distinction like first-generation (UoG, BDU), second-generation (Wollo,DBU, \& DMU) and third-generation (DTU \& Welidya). The staff's place of birth can affect the satisfaction level of university teachers. Staffs that came from a rural area have more satisfaction than that of an urban area as indicated by Table 4. The study showed that academic staffs have no any position more likely to satisfied than that of top positions (managements) $(\mathrm{OR}=0.199$, P-value $=0.007)$. Top management may be overly busy in a different university activity, due to this they have no enough time to take rest and to interact with their families. Another similar study supports this founding, such as the study conducted by Menon et al. (2008) using a logistic regression model. According to the findings, job satisfaction influenced by university level (teachers working at lower education levels reported greater satisfaction than their higher-level counterparts); satisfaction with the school climate; and satisfaction with the degree to which the teacher had attained his/her professional goals. And also, another study conducted by Ibrahim et al. (2014) shows that the campus environment was the most statistically significant predictor of satisfaction, followed by the management of institute and support services.

The study revealed in Table 4 that university staffs that have a set of goals to do his/her job and carriers or staffs that have a responsibility in his/her day to day activity more likely to satisfied with their activity. The degree of opinion about the chance of advancement for university staff increased from strongly disagree to strongly agree as the satisfaction level increased. Salary is also a major factor in staff's satisfaction/dissatisfaction. University staff that have less salary more likely to be dissatisfied by their work. They have more intentions to leave university. Studies conducted by Singh (2013), Uddin et al., 2016, Keshtkaran (2006) and Menon et al. (2008) support this founding. 
A sense of achievement and a feeling of accomplishment about our day to day activity increase the satisfaction level of employees. Workers that internalize his/her achievement; he/she got satisfaction or not based on the activity. The work condition properly affects the satisfaction level of employees. The work condition seems satisfactory, making your own decision and create a balance between his/her work and home life directly increases the staff's satisfaction. And also works by itself affect the level of satisfaction (see Table 4). For example, excessive levels of stress at work and the system of working hours negatively affect the satisfaction of employees. This study supported by Bhatnagar and Srivastava (2011), conducted a study to develop scale and measure the job satisfaction status of medical teachers. In this study, results showed that job satisfaction of faculties was at "generally satisfied or not "on the Likert scale. They felt most dissatisfied with work rewards, working condition and sense of work achievement.

\section{Conclusion}

Overall, this study tries to give a conclusion based on the findings. $34.4 \%$ of teachers from the sample were satisfied and about $35 \%$ of the sample university staff strongly dissatisfied and satisfied. $22.1 \%$ of the staff in Amhara state university has the interest to leave employer University and searching for other jobs. Form this study variable like marital status, educational level, religion, region, service years, workers respective, net income and supermarket $\&$ bank (business center) are not significantly related to job satisfaction in the chi-square association and in the ordinal logistic model. Variables that are significantly related to job satisfaction in the case of an ordinal logistic model using proportional odds model sex, age, place of birth, position of the staff, employer University, turnover of intention, advancement, achievement, responsibility, salary, work condition and work itself. Job satisfaction and turnover intention are strongly related. Staff, have no interest to leave the university; that means they are satisfied with the current situations of the university.

\section{Recommendation}

Based on the findings of this study:

- Male academic staffs are more likely to satisfied than that of female academic staff. Thus, attention should be given to female academic staff within the university.

- The universities should try to maximize academic staff satisfaction in order to have senior staff because academic staff satisfaction and turn over intention have an inverse relationship.

- The universities and concerned bodies should work on narrowing the gap between the first, second and third-generation because they are significantly different in academic staff satisfaction.

- Further researches in this area are recommended to include other factors that have impact on academic staff satisfaction.

\section{Abbreviations}




\begin{tabular}{ll} 
OLR & Ordinal Logistic Regression \\
CART & College of Agriculture and Resource Technology \\
CBEC & College of Business and Economics \\
CMHS & College of Medicine and Health Science \\
CNCS & College of Natural and Computational Science \\
CSSH & College of Social Science and Humanities \\
IOTE & Institute of Technology \\
UK & United Kingdom \\
Ref & Reference \\
OR & Odds ratio \\
UoG & University of Gondar \\
BDU & Bahirdar University \\
PhD & Doctor of Philosophy \\
BSc & Bachelor of Science \\
BA & Bachelor of Art \\
Str.agree & Strongly Agree \\
Str.disagree & Strongly Disagree \\
\hline
\end{tabular}

\section{Declarations}

Ethics approval and consent to participate: 'Not applicable'

Consent for publication: 'Not applicable'

Availability of data and material: 'Applicable'

Competing interests: 'Not applicable'

Funding: University of Gondar, Gondar, Ethiopia.

\section{Authors' Contributions}


The principal investigator (KA) and $\mathrm{KM}$, had a major contribution in designing and planning of the research; and in extraction and analysis of the data as well. Similarly, KA, KM, YA, DM, Al, and JH was assisted in preparing and designing the questionnaires, conducting pretest and data collection from all universities. All authors read and approved the final manuscript.

Acknowledgments: First and foremost, thanks to God and his lovely mother St. Mariam.

The authors would like to thank University of Gondar for the grant (financial aid) and writing cooperation letter, and all necessary conditions during this study.

\section{Authors' information}

Kidanemariam Alem ${ }^{1}$, Kasim Mohammed ${ }^{2}$, Yibeltal Arega ${ }^{2}$, Dessie Melese ${ }^{2}$, Adem Ibrahim ${ }^{3}$, Jemila Hussen $^{3}$

${ }^{1}$ Department of Biostatistics, School of Public health, College of Health Sciences, Mekelle University, Mekelle, Ethiopia.

${ }^{2}$ Department of Statistics, College of Natural and Computational Sciences, University of Gondar, Gondar, Ethiopia.

${ }^{3}$ Department of Management, College of Business and Economics, University of Gondar, Gondar, Ethiopia.

\section{References}

AGARWALA T 2007. Strategic human resources management

$A L I$, N. 2015. Factors affecting overall job satisfaction and turnover intention.

ARMSTRONG, M. 2006. Strategic human resources management: a guide to action. 3rd ed. London and Philadelphia: Kogan Page Limited

ASEGID, A., BELACHEW, T. \& YIMAM, E. 2014. Factors influencing job satisfaction and anticipated turnover among nurses in Sidama Zone Public Health facilities,South Ethiopia.

BHATNAGAR, K. \& SRIVASTAVA, K. 2011. A Preliminary Study to Measure and Develop Job Satisfaction Scale for Medical Teachers.

Brookes, M.(2002)Evaluting the Student Experience: An approach to Managing and Enhancing quality in Higher education. journal of Hospitality leisure, Sport and Tourism, pp 17-26.

CHO, Y. \& LEWIS, G. 2012. Turnover intention and turnover behaviour: implication for retaining federal employees. 
DONALD, M. F., LUCIA, M. E. \& VICTOR, N. M. 2016. The relationship between job satisfaction and organizational commitment among academic staff members in a selected higher education institution.

EUROPEAN COMMISSION 2002. Employment

EVANS, L. 1998. Teacher Morale, Job Satisfaction and Motivation.

GETIE, G. A., BETRE, E. T. \& HARERI, H. A. 2013. Assessment of Factors Affecting Turnover Intention Among Nurses Working at Governmental Health Care Institutions in East Gojjam, Amhara Region, Ethiopia.

Harry,M.,Maull,R., \& Smart, A. (2007), Customer satisfaction and Service Quality in UK Financial services, International journal of operations and Production Management. vol.27, No.9 pp.999-1019.

IBRAHIM, M. Z., RAHMAN, M. N. A. \& YASIN, R. M. 2014. Determining factors of students' satisfaction with Malaysian skills training institutes.

JYOTI, J. \& SHARMA, R. 2006. Job satisfaction among school teachers. 18, 349-363.

KESHTKARAN, A. 2006. A Study of Job Satisfaction and its Demographic Correlates of Faculty Members at Shiraz University of Medical Sciences.

MATHIEU, J. E. 1991. A Cross-Level Nonrecursive Model of the Antecedents of Organizational Commitment and Satisfaction. 76, 607-618.

MENON, M. E., PAPANASTASIOU, E. \& ZEMBYLAS, M. 2008. examining the relationship of job satisfaction to teacher and organizational variables: evidence from Cyprus.

OSTROFF, C. 1992. The Relationship Between Satisfaction, Attitudes, and Performance: An Organizational Level Analysis 77, 963-974.

RAMADHANI, S. 2014. Factors influencing job satisfaction and turnover intentions in commercial banks. Richardson, J.C. (2003). Examining Social Presence in On-line Courses in relation to students Perceeived Learning and Satisfaction. journal of Asynchronous Learning Nt, A Publication of the Sloan Consort. Vol.7 Issue 1.

SCOTT, M.,2004. Perceptions of Fundamental Job Characteristics and their level of Job Satisfaction.

SINGH, R. G. 2013. Factors Explaining Job Satisfaction Among Hospital Employees.

UDDIN, M. J., KABIR, M. Z., RAHMAN, M. M. \& AKHTER, R. 2016. Factors affecting overall job satisfaction of mobile telecom employees in Bangladesh. http://www.ijisr.issr-journals.org/ . 
Zeithaml, V.A., Bitner M.J, \&GlemlerD.D. (2009). Service marketing, Integrating Customer Focus Across the Firm. $5^{\text {th }}$ Ed., McGraw-Hill publishing company, New Delhi. 